\title{
Novel missense variant of CACNA1A gene in a Slovak family with episodic ataxia type 2
}

\author{
Andrea Petrovicova ${ }^{a}$, Miroslav Brozmann ${ }^{\mathrm{a}}$, Egon Kurca ${ }^{\mathrm{b}}$, Tibor Gobo ${ }^{\mathrm{a}}$, Jana Dluha ${ }^{\mathrm{b}}$, Klaudia Kalmarova ${ }^{\mathrm{b}}$, Vladimir Nosal ${ }^{\mathrm{b}}$, \\ Martina Hikkelovac, Adriana Krajciovac, Tatiana Burjanivova ${ }^{\mathrm{d}}$, Stefan Sivak ${ }^{\mathrm{b}}$
}

Introduction. Episodic ataxias (EAs) are rare dominantly inherited neurological disorders characterized by recurrent episodes of ataxia lasting minutes to hours. The most common subtype is EA type 2 (EA2) caused by pathogenic variants of calcium voltage-gated channel subunit alpha1 A gene (CACNA1A) on chromosome 19p13.

Subjects and Methods. We examined a Slovak three-generation family. Genomic DNA of the family members was extracted from peripheral blood and amplified by polymerase chain reaction. CACNA1A variants were screened by Sanger sequencing.

Results. We identified four family members with recurrent episodes of ataxia. Complex differential diagnosis was performed. Genetic analysis with direct sequencing revealed a novel heterozygous variant of CACNA1A - c.5264A $>G$ (p.Glu1755Gly) located in the pore loop of domain IV of calcium channel alpha-1A subunit.

Conclusion. We identified a novel missense variant of a voltage-dependent P/Q-type calcium channel alpha-1A subunit in a Slovak three-generation family with recurrent episodes of ataxia. The heterozygous missense variant resulted in changing a highly conserved glutamic acid within the pore loop of domain IV.

Key words: episodic ataxia type 2, novel variant, CACNA1A, pore loop

Received: July 1, 2016; Accepted with revision: December 20, 2016; Available online: January 13, 2017 https://doi.org/10.5507/bp.2016.066

${ }^{a}$ Department of Neurology, Faculty Hospital, Constantine Philosopher University, Spitalska 6, 94901 Nitra, Slovak Republic ${ }^{b}$ Clinic of Neurology, Jessenius Faculty of Medicine in Martin, Comenius University in Bratislava, Kollarova 2, 03659 Martin, Slovak Republic 'Alphamedical, s.r.o, Laboratory of Medical Genetics, Radlinskeho 9, 81000 Bratislava,

${ }^{d}$ Department of Molecular Biology, Jessenius Faculty of Medicine in Martin, Comenius University in Bratislava, Mala Hora 4b, 03659 Martin, Slovak Republic

Corresponding author: Stefan Sivak, e-mail:sivak@jfmed.uniba.sk

\section{INTRODUCTION}

Episodic ataxias (EAs) are rare dominantly inherited neurological disorders characterized by recurrent episodes of imbalance and a lack of coordination lasting minutes to hours and eventually, in later stages of the disease, by neurological signs or progressive cerebellar dysfunction between the episodes. So far 8 subtypes of EAs have been described ${ }^{1}$. The most common subtype is EA type 2 (EA2) caused by pathogenic variants of calcium voltagegated channel subunit alpha1 A gene (CACNA1A) on chromosome 19 p13 (ref. $^{2}$ ). We describe a three-generation family with four members affected by EA2 with a novel missense variant of CACNAIA.

\section{SUBJECTS AND METHODS}

A Slovak three-generation family were examined at the Department of Neurology, Faculty Hospital in Nitra, Slovakia between the years 2014 and 2016. Due to the typical history of recurrent episodes of ataxia, clinical findings, and exclusion of other differential diagnoses, we suspected EA2 in four family members (Fig.1). Clinical neurological examinations and genetic blood tests were performed in the patients and other healthy family mem-

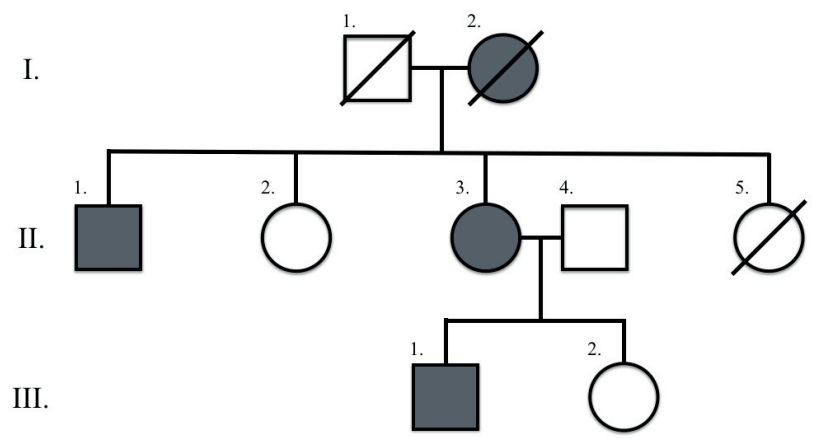

Fig. 1. Family pedigree. The family comprised of four affected members in three generations. Roman numerals (I-III) give the generation, arabic numerals (1-3) the individuals within one generation. Square - male, circle - female, filled symbol - affected subject, blank symbol - unaffected subject, diagonal line - deceased subject.

bers after obtaining their written informed consent. The Ethics committee of Jessenius Faculty of Medicine at Comenius University (Slovakia) approved the study. Written informed consent was obtained from the family members.

DNA was extracted from peripheral blood using standard procedures, all according to the manufac- 
turer's protocol. To isolate DNA, NucleoSpin ${ }^{\circledR}$ Blood kit (Macherey-Nagel GmbH \& Co. KG, Germany) was used. PCR was performed in $10 \mu \mathrm{L}$ volume using $40 \mathrm{ng}$ of template DNA, 2X Maxima Hot Start PCR Master Mix (Thermo Fisher Scientific Inc., USA) and 10 pM of each primer. All primer sequences are available on request. PCR cycling conditions were as follows: initial denaturation $95{ }^{\circ} \mathrm{C} 5 \mathrm{~min}$; 35 cycles of $95^{\circ} \mathrm{C} 30 \mathrm{~s}$; hybridization $57-66{ }^{\circ} \mathrm{C} 30 \mathrm{~s}$; polymerization $72{ }^{\circ} \mathrm{C} 30 \mathrm{~s}$; and final polymerization $72{ }^{\circ} \mathrm{C} 10 \mathrm{~min}$ with cooling to $4{ }^{\circ} \mathrm{C}$. Amplified products were treated with Exo I (Exonuclease I; Thermo Fisher Scientific Inc., USA) and FastAP (Thermosensitive Alkaline Phosphatase; Thermo Fisher Scientific Inc., USA). The sequencing reaction was carried out using BigDye ${ }^{\circledR}$ Terminator v3.1 kit on the ABI PRISM 3130 Genetic Analyzer (Applied Biosystems, USA). For analyses Geneious 8.1 software was used. PolyPhen-2 and MutationTaster were used to evaluate the effect of mutation on protein function ${ }^{3,4}$.

\section{RESULTS}

A 21-year-old man (III-1) reported recurrent attacks of severe gait instability with vertigo, nausea, vomiting, sensation of heat in the body, and dysarthria provoked by stress. The duration of the ataxic episodes usually ranged from 5 to $24 \mathrm{~h}$. Relapses began at the age of 3 occurring 3 times a week. A neurological examination showed persistent symmetric gaze-evoked horizontal nystagmus and mild mental retardation $(I Q=75)$. The patient reported no progressive neurological symptoms. He suffered from migraine with visual aura occurring 5 times a month. Brain MRI revealed a mild frontal atrophy. Prescription of acetazolamide led to suppression of the ataxic episodes and amelioration of migraine. Genetic analysis with direct sequencing revealed a novel heterozygous $C A C N A 1 A$ (ENST00000360228) variant c.5264A $>$ G. Codon GAA coding for glutamic acid (Glu) at position 1755 was substituted in one allele by codon GGA for glycine (Gly). The variant resulting in p.Glu 1755Gly (ENSP00000353362) was evaluated with the prediction tool PolyPhen-2 as "probably damaging" with a score of 1.0 , and with MutationTaster as "disease causing" with probability 1.0.

His 53-year-old mother (II-3) suffered from recurrent episodes of ataxia, nystagmus, dysarthria, and triptanunresponsive migraine with visual aura starting at the age of 17. The episodes lasted 12-24 h, occurring once a week. An interictal neurological examination revealed only mild cognitive deficit. No neurological progression was present. Brain MRI was normal. She began treatment with acetazolamide 3 times a day (500-250-250 mg) and reported a decrease in severity and frequency of ataxia and migraine attacks. A genetic analysis of $C A C N A 1 A$ revealed the same novel variant p.Glu1755Gly.

A 46-year-old man (uncle, II-1) reported a history of reccurrent episodes of ataxia, vertigo, nausea, and sensation of heat starting at the age of 13 (once a month). The duration of the ataxic episodes usually ranged from 5 to 48 h. A neurological examination revealed mild cogni- tive deficit, horizontal gaze-evoked nystagmus, bilateral neocerebellar and paleocerebellar syndrome, and spastic quadruparesis with spastic-ataxic gait of moderate severity and need of crutches. The progressive neurological disability had developed over the past ten years. Brain MRI revealed a mild cerebellar atrophy. He underwent complex differential diagnosis which ruled out other diseases (including spinocerebellar ataxias $1,2,3,6$; based on genetic analysis). Analysis of $C A C N A 1 A$ revealed the same novel variant p.Glu 1755 Gly.

The fourth affected family member was a grandmother (I-2). Unfortunately, she unexpectedly died when she was 70 years old, before we could examine her. She suffered from recurrent relapses of vertigo, gait and postural instability, and dysarthria. We do not have reliable information about the duration or frequency of ataxia episodes. She was never examined for EA2 or treated with acetazolamide.

In the rest of the family (II-2,II-4,III-2), neurological findings were normal. Genetic analyses did not reveal the variant of CACNA1A in healthy family members. However they reported epilepsy (II-2), headache (II2,II-5), and sudden death due to hemorrhagic stroke (II$5)$.

\section{DISCUSSION}

EA2, the most common subtype of EAs, is caused by pathogenic $C A C N A 1 A$ variants. $C A C N A 1 A$ encodes the pore-forming and voltage-sensing alpha-1A subunit of the voltage-dependent P/Q-type calcium channel ( $\left.\mathrm{Ca}_{\mathrm{v}} 2.1\right)$. It is expressed throughout the central nervous system, particularly in cerebellar Purkinje and granule cells, as well as at neuromuscular junctions ${ }^{5,6}$. CACNA1A variants are associated with several dominantly inherited disorders with episodic or progressive neurological symptoms, such as EA2 (MIM\# 108500), familial hemiplegic migraine type 1 (FHM1, MIM\#141500) ( ref. $^{7}$ ), spinocerebellar ataxia type 6 (SCA6, MIM\#183086) ( (ef. $^{8}$ ), epilepsy ${ }^{9}$, and myasthenic syndrome ${ }^{10}$. Alpha-1A subunit is a protein which consists of about 2500 amino acids. Amino-acid sequence is organized in four domains (I-IV), each containing six transmembrane segments (S1-S6) and a membraneassociated loop between S5 and S6 segments ${ }^{11}$. S4 segments serve as voltage sensors that activate and initiate a conformational change that opens the channel pore. S5 and S6 segments and the membrane-associated pore loop between them form the lining of the voltage-gated calcium channel. Selectivity and permeability are achieved by interaction of calcium ions with high-affinity binding sites in these pore loops ${ }^{11}$.

We describe a family affected by EA2 with a novel point variant of the CACNAIA found in four members of a three-generation family. So far more than 60 variants of CACNA1A (nonsense, missense, as well as CAGtriplet expansions) have been identified and associated with EA2 (ref. ${ }^{12}$ ). Several missense variants in pore-loop regions have been described in the medical literature so far $^{12-24}$. Structural changes in pore-loop regions can lead to 
Table 1. Clinical comparision of the two CACNA1A variants p.Glu1755Gly and p.Glu1755Lys.

\begin{tabular}{|c|c|c|c|c|c|c|c|c|c|c|c|}
\hline \multirow[b]{2}{*}{ Variant p. } & \multirow[b]{2}{*}{$\begin{array}{c}\text { age of } \\
\text { onset } \\
\text { (years) }\end{array}$} & \multicolumn{3}{|c|}{ Episodic ataxia } & \multicolumn{4}{|c|}{ Interictal signs } & \multirow[b]{2}{*}{$\begin{array}{c}\text { Migraine } \\
\text { (Yes/No/ } \\
\text { Unk) }\end{array}$} & \multirow[b]{2}{*}{$\begin{array}{c}\text { Aura } \\
\text { (Yes/No/ } \\
\text { Unk) }\end{array}$} & \multirow[b]{2}{*}{ Ref. } \\
\hline & & $\begin{array}{c}\text { Affected } \\
\text { members } \\
(n)\end{array}$ & $\begin{array}{c}\text { Symptom } \\
\text { duration } \\
\text { (hours) }\end{array}$ & $\begin{array}{c}\text { Response } \\
\text { to acetazol- } \\
\text { amide (Yes/ } \\
\text { No/Unk) }\end{array}$ & $\begin{array}{c}\text { Progression } \\
\text { (Yes/No) }\end{array}$ & $\begin{array}{c}\text { Cerebellar } \\
\text { ataxia } \\
(\text { Yes/No) }\end{array}$ & $\begin{array}{c}\text { Oculomotor } \\
\text { dysfunction } \\
\text { (Yes/No) }\end{array}$ & $\begin{array}{c}\text { Cognitive } \\
\text { impairment } \\
\text { (Yes/No/ } \\
\text { Unk) }\end{array}$ & & & \\
\hline Glu1755Gly & $3-17$ & 4 & $5-48$ & $2 / 0 / 2$ & $1 / 3$ & $1 / 3$ & $2 / 2$ & $3 / 0 / 1$ & $3 / 0 / 1$ & $3 / 0 / 1$ & $\begin{array}{l}\text { present } \\
\text { study }\end{array}$ \\
\hline Glu1755Lys & $30-40$ & 4 & $0.5-4$ & $1 / 0 / 3$ & $1 / 3$ & $1 / 3$ & $1 / 3$ & $0 / 0 / 4$ & $1 / 3 / 0$ & $0 / 4 / 0$ & 21 \\
\hline
\end{tabular}

Unk - unknown, n - number, Glu - glutamic acid, Gly - glycine, Lys - lysine

functional changes disabling activation or inactivation of calcium flux ${ }^{16}$. Our heterozygous missense p.Glu1755Gly variant resulted in negatively charged glutamic acid being substituted with hydrophobic uncharged glycine within the pore loop of domain IV. Glutamic acid at codon 1755 is a highly conserved amino acid from drosophila to man. Denier et al. described a family with a different missense variant at the same position (at position 1755): glutamic acid (Glu) was substituted for lysine (Lys) $\left(\right.$ ref. $\left.{ }^{21}\right)$. Comparision of both phenotypes is in the Table 1 . Both families (Denier's and ours) suffered from episodes of ataxia in combination with dysarthria, vertigo, nausea/ vomitus, and sensations of heat. Only some members of both families suffered from progressive ataxia and interictal oculomotor dysfunction. Progressive neurological dysability in our affected family member was more severe compared to Denier's family (moderate spastic-ataxic gait vs. mild ataxia). Our patients suffer from migraine with visual aura. The variant in Denier's family led to later onset of symptoms and shorter duration of ataxic episodes compared to our family (30-40 vs. 3-17 years and 0.5-4 vs. 5-48 h, respectively). Acetazolamide, which presumably stabilizes mutant calcium channels that fail to properly inactivate by decreasing $\mathrm{pH}$, was effective in both variants $^{16,25}$.

A small number of subjects and no functional study are the main limitations of our study. However, the functional relevance of the new variant is strongly supported by its presence only in the clinically affected members of the family; by its damaging impact predicted by two different prediction tools; by its position in a specific highly conserved protein region; and especially by its position in a place where another pathogenic variant has already been described (p.Glu1755Lys).

In conclusion, we identified a novel missense variant of alpha-1A subunit of the voltage-dependent P/Q-type calcium channel in a Slovak three-generation family with recurrent episodes of ataxia. The heterozygous missense variant p.Glu 1755 Gly resulted in changing a highly conserved glutamic acid within the pore loop of domain IV.

\section{ABBREVIATIONS}

CACNA1A, Calcium voltage-gated channel subunit alpha1 A gene; EA, Episodic ataxia; EA2, Episodic ataxia type 2; FHM1, Familial hemiplegic migraine type
1; Glu, Glutamic acid; Gly, Glycine; Lys, Lysine; PCR, Polymerase chain reaction; SCA6, Spinocerebellar ataxia type 6.

Acknowledgement: The authors are extremely grateful to the patients and their family for their collaboration. The authors wish to thank Ms. Hana Jesenska who assisted in proofreading of the manuscript. This work was supported with the project „PACS system in Research and Development“, ITMS code: 26210120004, co-financed from EU sources (ERDF) and with the Centre for Translational Medicine, ITMS code: 2622022022, cofinanced from EU sources.

Author contributions: SS, BT: literature search; SS, PA, KE, BT: manuscript writing; PA, BM, GT: family examination, SS, DJ, KK, NV, BT: analysis and interpretation of data; HM, KA: genetic testing and analysis.

Conflict of interest statement: The authors state that there are no conflicts of interest regarding the publication of this article.

\section{REFERENCES}

1. Conroy J, McGettigan P, Murphy R, Webb D, Murphy SM, McCoy B, Albertyn C, McCreary D, McDonagh C, Walsh O, Lynch S, Ennis S. A novel locus for episodic ataxia:UBR4 the likely candidate. Eur J Hum Genet 2014;22(4):505-10.

2. Ophoff RA, Terwindt GM, Vergouwe MN, van Eijk R, Oefner PJ, Hoffman SM, Lamerdin JE, Mohrenweiser HW, Bulman DE, Ferrari M, Haan J, Lindhout D, van Ommen GJ, Hofker MH, Ferrari MD Frants RR. Familial hemiplegic migraine and episodic ataxia type-2 are caused by mutations in the Ca2+ channel gene CACNL1A4. Cell 1996;87(3):543-52.

3. Adzhubei IA, Schmidt S, Peshkin L, Ramensky VE, Gerasimova A, Bork P, Kondrashov AS, Sunyaev SR. A method and server for predicting damaging missense mutations. Nat Methods 2010;7(4):248-9.

4. Schwarz JM, Cooper DN, Schuelke M, Seelow D. MutationTaster2: mutation prediction for the deep-sequencing age. Nat Methods 2014;11(4):361-2.

5. Westenbroek RE, Sakurai T, Elliott EM, Hell JW, Starr TV, Snutch TP, Catterall WA. Immunochemical identification and subcellular distribution of the alpha $1 \mathrm{~A}$ subunits of brain calcium channels. J Neurosci 1995;15(10):6403-18.

6. Nachbauer W, Nocker M, Karner E, Stankovic I, Unterberger I, Eigentler A, Schneider R, Poewe W, Delazer M, Boesch S. Episodic ataxia type 2: phenotype characteristics of a novel CACNA1A mutation and review of the literature. J Neurol 2014;261(5):983-91.

7. Ophoff RA, Terwindt GM, Vergouwe MN, van Eijk R, Oefner PJ, Hoffman SM, Lamerdin JE, Mohrenweiser HW, Bulman DE, Ferrari M, Haan J, Lindhout D, van Ommen GJ, Hofker MH, Ferrari MD, Frants RR. Familial hemiplegic migraine and episodic ataxia type-2 
are caused by mutations in the Ca2+ channel gene CACNL1A4. Cell 1996;87(3):543-52.

8. Zhuchenko O, Bailey J, Bonnen P, Ashizawa T, Stockton DW, Amos C Dobyns WB, Subramony SH, Zoghbi HY, Lee CC. Autosomal dominant cerebellar ataxia (SCA6) associated with small polyglutamine expansions in the alpha $1 \mathrm{~A}$-voltage-dependent calcium channel. Nat Genet 1997;15(1):62-9.

9. Jouvenceau A, Eunson LH, Spauschus A, Ramesh V, Zuberi SM Kullmann DM, Hanna MG. Human epilepsy associated with dysfunction of the brain P/Q-type calcium channel. Lancet 2001;358(9284):801-7.

10. Jen J, Wan J, Graves M, Yu H, Mock AF, Coulin CJ, Kim G, Yue Q, Papazian DM, Baloh RW. Loss-of-function EA2 mutations are associated with impaired neuromuscular transmission. Neurology 2001;57(10):1843-8.

11. Catterall WA. Voltage-gated calcium channels. Cold Spring Harb Perspect Biol 2011;3(8):a003947.

12. Mantuano E, Veneziano L, Spadaro M, Giunti P, Guida S, Leggio MG Verriello L, Wood N, Jodice C, Frontali M. Clusters of non-truncating mutations of $\mathrm{P} / \mathrm{Q}$ type $\mathrm{Ca} 2+$ channel subunit $\mathrm{Ca}(\mathrm{v}) 2.1$ causing episodic ataxia 2. J Med Genet 2004;41(6):e82.

13. van den Maagdenberg AM, Kors EE, Brunt ER, van Paesschen W, Pascual J, Ravine D, Keeling S, Vanmolkot KR, Vermeulen FL, Terwindt GM, Haan J, Frants RR, Ferrari MD. Episodic ataxia type 2. Three novel truncating mutations and one novel missense mutation in the CACNA1A gene. J Neurol 2002;249(11):1515-9.

14. Wan J, Khanna R, Sandusky M, Papazian DM, Jen JC, Baloh RW. CACNA1A mutations causing episodic and progressive ataxia alter channel trafficking and kinetics. Neurology 2005;64(12):2090-7.

15. Jen J, Kim GW, Baloh RW. Clinical spectrum of episodic ataxia type 2. Neurology 2004;62(1):17-22.

16. Yue Q, Jen JC, Nelson SF, Baloh RW. Progressive ataxia due to a missense mutation in a calcium-channel gene. Am J Hum Genet 1997;61(5):1078-87.
17. Bürk K, Kaiser FJ, Tennstedt S, Schöls L, Kreuz FR, Wieland T, Strom TM, Büttner T, Hollstein R, Braunholz D, Plaschke J, Gillessen-Kaesbach G, Zühlke C. A novel missense mutation in CACNA1A evaluated by in silico protein modeling is associated with non-episodic spinocerebellar ataxia with slow progression. Eur J Med Genet 2014;57(5):20711.

18. Cuenca-León $E$, Banchs I, Serra SA, Latorre P, Fernàndez-Castillo $\mathrm{N}$, Corominas R, Valverde MA, Volpini V, Fernández-Fernández JM, Macaya A, Cormand B. Late-onset episodic ataxia type 2 associated with a novel loss-of-function mutation in the CACNA1A gene. J Neurol Sci 2009;280(1-2):10-4.

19. Ducros A, Denier C, Joutel A, Cecillon M, Lescoat C, Vahedi K, Darce F, Vicaut E, Bousser MG, Tournier-Lasserve E. The clinical spectrum of familial hemiplegic migraine associated with mutations in a neuronal calcium channel. N Engl J Med 2001;345(1):17-24.

20. Geerlings RP, Koehler PJ, Haane DY, Stam AH, de Vries B, Boon EM, Haan J. Head tremor related to CACNA1A mutations. Cephalalgia 2011;31(12):1315-9.

21. Denier C, Ducros A, Durr A, Eymard B, Chassande B, Tournier-Lasserve E. Missense CACNA1A mutation causing episodic ataxia type 2 . Arch Neurol 2001;58(2):292-5.

22. Carrera P, Piatti M, Stenirri S, Grimaldi LM, Marchioni E, Curcio M, Righetti PG, Ferrari M, Gelfi C. Genetic heterogeneity in Italian families with familial hemiplegic migraine. Neurology 1999;53(1):26-33.

23. Spacey SD, Hildebrand ME, Materek LA, Bird TD, Snutch TP. Functional implications of a novel EA2 mutation in the P/Q-type calcium channel. Ann Neurol 2004;56(2):213-20.

24. Bertholon P, Chabrier S, Riant F, Tournier-Lasserve E, Peyron R. Episodic ataxia type 2: unusual aspects in clinical and genetic presentation. Special emphasis in childhood. J Neurol Neurosurg Psychiatry 2009;80(11):1289-92.

25. Bain PG, O'Brien MD, Keevil SF, Porter DA. Familial periodic cerebellar ataxia: a problem of cerebellar intracellular $\mathrm{pH}$ homeostasis. Ann Neurol 1992;31(2):147-54. 